\title{
Recommendations on Environmental Impact Analysis for Developing Countries
}

On the basis of papers presented at the International Conference on Environmental Impact Analysis for Developing Countries* and the ensuing discussions, there was general agreement among the participants on the following recommendations:

1. EIA should be made mandatory in all developing countries. Those countries that do not at present have the necessary legislative frameworks should take immediate steps to make EIA compulsory. Laws and regulations, however, by themselves, are not enough. All efforts should be made to ensure that the legal requirements are actually and properly implemented. UNEP and UNDP should assist those countries that require assistance to develop appropriate legal framework and ensure due implementation.

2. Methodologies that are currently available for EIA are generally not appropriate for developing countries. Much of the work that is now being carried out in this area is somewhat academic in nature, such that its operational applications leave much to be desired. Most urgently needed are cost-effective and efficient means of carrying out, and then implementing, EIA as an integral component for achieving sustainable development. It is also necessary to ensure that the methodologies developed would enable developing countries to carry out EIA at limited cost and with the expertise available, and that it can be completed within a reasonable time-frame. Equally, EIA must consider both positive and negative environmental impacts. National and international organizations should work together to develop operational EIA methodologies. Special consideration should be given as to how best to handle the environmental impacts of small-scale industries.

3. While developing countries can get information on EIAs that are carried out in developed countries, southsouth information transfer in this area is currently almost negligible. What is immediately needed is an objective and reliable review of the current status of the effectiveness of using EIA in developing countries, the methodologies employed and their relative merits and constraints, the main features of their implementation processes, and the emerging trends. As a first step, it is recommended that UNEP, UNDP, and the Asian Development Bank (ADB), prepare such a review for the Asian region.

4. In many developing countries, considerable problems and constraints exist for carrying out EIAs. There is an urgent need to establish clear and unambiguous guidelines for EIA that would be acceptable to relevant Ministries, United Nations Agencies, Asian and other Development Banks, and bilateral aid organizations. It is recommended that National Workshops be organized, which would include all the relevant parties-including environmental nongovernmental organizations - to develop acceptable guidelines.

5. It is a very difficult, if not impossible, task for analysts in developing countries to find good case-studies as examples of cost-effective EIAs that have been carried out in other developing countries. It would be very helpful if good EIA case-studies from developing countries could be identified and then published as a Handbook that would be easily available to those who require them. It is accordingly recommended that:

\footnotetext{
* See pp. 66-9 of our latest issue.-Ed
}

i) UNEP, UNDP, and the International Society for Ecological Modelling (ISEM), work together to prepare such a Handbook;

ii) UNIDO and the International Association for Clean Technology (IACT) collaborate to prepare a Handbook of good EIA case-studies from industry; and

iii) UNDP, UNEP, and the International Water Resources Association, work together to prepare a similar Handbook for the water sector.

6. Very little monitoring and follow-up work has been done in developing countries to see how the forecasts made by the initial EIA studies compare with the actual impacts after the implementation of the projects. If the reliability of the EIA methodologies is to be improved, environmental impact monitoring after project implementation is an essential requirement. It is recommended that national and international organizations collaborate on a series of specific case-studies in which EIA forecasts made during the project-approval phase are compared with the observed impacts after implementation. Results of such intercomparison studies should be made widely available.

7. Risk analysis and social impact analysis should be integrated within the framework of EIA methodologies, risk and social impact analyses being still less advanced than is the case with EIA. UNDP, UNIDO, UNEP, and ADB, in collaboration with IACT and ISEM, should sponsor research to develop operational methodologies for risk analysis and social impact analysis.

8. Public participation being an important requirement for Environmental Impact Assessment, UNEP, UNIDO, and UNDP, should sponsor studies to review the extent of public participation and their relative effectiveness in conducting EIA studies in various developing countries. Such comparative studies would assist countries to determine the best alternative available to them to ensure public involvement in EIA.

9. Education and training in EIA are essential for all developing countries, with training of trainers needing priority attention. All international and national organizations should encourage education and training in EIA, to develop adequate expertise in developing countries. The ultimate objective of such education and training exercises should be to develop an adequate number of professionals in each country who would be able to carry out EIA with indigenous expertise.

10. The Pollution Control Research Institute of India should be complimented for organizing a very successful, productive, and much-needed Conference on EIA for Developing Countries. The Institute should be further encouraged to convene and conduct seminars, workshops, and training courses, on EIA for specific industrial sectors, individually or in cooperation with appropriate national and international organizations. One of the priority sectors could be EIA of thermal power-stations.
Asit K. Biswas, President
International Society for Ecological Modelling 76 Woodstock Close
Oxford $O X 28 D D$
England, $U K$.

\section{The World Association of Soil and Water Conservation: Activities in Europe}

Europe needs an effective soil and water conservation lobby. At present, there is no single organization which can bridge the gaps between Europe's laboratories and its agri- cultural lands, its academics and its engineers, its conservationists and its farmers, its specialists and the "ordinary people'. There is no organization which can mount an 
effective political campaign to promote soil conservation at national and international levels across Europe. The World Association of Soil and Water Conservation (WASWC) in Europe would like to help to create such an organization.

The purpose of the WASWC is to encourage the wiseand that means sustainable-use of soil and water resources. At its foundation in 1983, the WASWC's manifesto pledged the organization to serve and inform soil conservation workers and to champion the cause of resource conservation in the world at large. Soil and water conservation is everybody's responsibility, but that responsibility rests especially heavily on scientists, agriculturalists, educators, conservation professionals, and upon those who make the laws and regulations which affect the use and abuse of the land. At present, the world's soil resources are being wasted through neglect and mismanagement. The information, the technologies, and the policies, that are needed to solve this problem must be produced and communicated.

\section{Five Main Objectives}

The WASWC has five objectives: (1) It tries to monitor soil and water conservation needs and practices, and to support conservation action in each nation and worldwide; (2) It tries to create a world-wide information exchange through workshops and publications; (3) It seeks to link soil conservationists with policymakers; (4) It tries to promote good conservation research and practice, and (5) It seeks to build up public awareness of the need for soil and water conservation.

The WASWC in Europe has the particular aim of serving the needs of Europe's soil conservationists. Europe presents many special soil conservation problems, most of which are political and administrative rather than technological.

Europe is a complex and divided region but it is also striving towards international integration and understanding, both within and between, its Eastern and Western ideological camps. It is an underdeveloped region as far as soil and water conservation is concerned. Soil and water conservation activities are scattered and uncoordinated even within its individual nations.

Despite this, Europe produces much that is very good in both soil conservation research and practice. Sadly, much of this good work remains hidden behind the barriers of language and different national practices. As a result, mistakes are duplicated and solutions neglected. More than any other region, the priority for WASWC activity in Europe is the creation of an international network for the communication of ideas and experience. The most important barrier to such communication is that between East and West.

For most of the world, soil conservation has to be undertaken within the context of an agricultural system which is striving to increase production. In much of Europe, this is not an issue. The region is already an effective, high-technology, producer of agricultural products and, in the 1980s, it suffers more economic problems from overproduction than underproduction. It does not face rapidly expanding populations, indeed several nations worry more about population decline. All across Europe, there is a growing concern about the quality rather than the quantity of agricultural production, and there is an increasing willingness to trade off lower agricultural yields for an improved environmental quality. The search for a low input, ecologically valid, sustainable agricultural system producing 'uncontaminated' foodstuffs is under way. The concerns of soil and water conservation could play a key role in the design of new systems of environmentally sensitive land management.
Europe was the continent of heavy industry. Today, many regions face the problems, not of development, but of the rehabilitation of landscapes which have been devastated either directly (e.g. by mining or heavy industry), or indirectly (by industrial by-products and emissions). The problems of industrial pollution and of post-industrial reconstruction are more important in Europe than on any other continent. Consequently, land reclamation is set to be a major focus for WASWC activities in Europe. Indeed it is scheduled to become the main subject of the Association's second European meeting.

Finally, Europe includes several of the world's major donors of international development aid. As with much of Europe's activity, at present these works are fragmented and uncoordinated. There is enormous scope for international cooperation in the provision of aid to nations of the Third World. Such activities could serve the dual purpose of improving Europe's capacity to field effective development aid, and at the same time of improving mutual understanding and training in soil and water conservation in Europe's constituent nations.

\section{Other Possibilities of Collaboration}

There are, of course, many other possible areas for WASWC development in Europe. These include the special problems of erosion control and the restoration of degraded lands in the Mediterranean region. The needs here include ideas and committed workers who are willing to introduce a new initiative and to carry it through. The WASWC needs new members, new workers, new ideas, and new programmes. It is happy to work alone, but happier to work in cooperation with the whole range of other European organizations with interests in the promotion of soil conservation and conservation-orientated farming.

Current WASWC activities focus on the problem of communication. To date, the WASWC has cosponsored the meetings of the International Soil Conservation Organization in Venezuela and Thailand, and it is heavily involved with the next ISCO meeting in Ethiopia and Kenya. In 1987 it coorganized a workshop on 'Soil and Water Conservation on Steeplands' in Puerto Rico, and it is chief international sponsor for a second 'International Workshop on Conservation Farming on Hillslopes' in Taiwan. In 1990, the WASWC will organize its own international conference to review the state-of-the-art in international soil conservation and to coordinate its own research network. Meanwhile, the Association publishes a quarterly Newsletter and nurses the ambition to launch its own 'International Journal of Soil and Water Conservation'.

\section{European Events}

In Europe, WASWC is involved in three meetings. The first was a session on 'Soil Conservation: Policies and Practices' which inaugurated the British Geomorphological Research Group's Symposium on 'Soil Erosion of Agricultural Land', which was held in Coventry, England, in January 1989. This session, attended by over one hundred delegates and including contributions from 12 nations, drew media attention through a report in the Times (London) on 3 January 1989.

During 1-3 September 1989, the WASWC (Europe) convenes a workshop entitled: 'Geoecological Approaches to Land Reclamation' as a special symposium of the Second International Conference on Geomorphology and Geoecology. The WASWC Workshop will be held in Bonn, F.R. of Germany, as a prelude to the main Conference. This will focus on the reconstruction of soils, hazard mitigation, and the control of erosion and sediment pollution on devastated lands.

Later, during 20-23 November 1989, the WASWC (Europe), in support of the larger WASWC focus on agri- 
culture in steeplands, cosponsors the 'International Conference on Headwater Control' in Czechoslovakia. This meeting concerns the problems of integrated land management in highlands and headwater regions. The WASWC shares its sponsorship with the International Union of Forest Research Organizations (IUFRO), the Czechoslovakian Scientific and Technical Society, and the Agricultural University of Prague.

More lastingly, the WASWC is involved in an aggressive campaign to increase soil conservation awareness. However, it still has a long way to go to become a world movement in more than name. In this respect, Europe holds a key position. At present, the movement is dominated by its supporters in the Americas. If it is truly to become a world movement, then it must also have major strength in Europe and elsewhere. Indeed, the success of the World Association of Soil and Water Conservation depends heavily on Europe.

A strong soil and water conservation movement would also be of major benefit to Europe, and the cause of integrated landscape management. Linguistic and nationalistic barriers have kept European soil and water conservation research in the shadows. Few individual nations, let alone the EEC and CMEA (Comecon) supranational structures, sponsor effective arrangements for soil and water conservation. Few nations in Europe really know much about the achievements of the research workers and practitioners among their neighbours. The result is that much good work is being wasted, much time is being lost in unnecessary duplication, and many good projects are lost through lack of personnel and public support. An international organization committed to work in Europe and also committed to conservation, education, and the creation of policy, is just what is needed. The WASWC (Europe) could be that organization.

WASWC membership details can be obtained from: W.C. Moldenhauer, Executive Secretary, WASWC, 317 Marvin Avenue, Volga, South Dakota, USA, or from the Soil and Water Conservation Society, N.E. Ankeny Road, Ankeny, Iowa, USA. Activities in the European area are currently being coordinated by the undersigned.

\author{
Martin J. Haigh \\ WASWC Vice-president (Europe) \\ Geography Unit \\ Oxford Polytechnic \\ Headington, Oxford \\ England, $U K$.
}

\section{A. Biological Diversity}

\section{The Conservation of the Biological Riches of the} World

40-years' goal:- To slow the rate of species extinction to less than twice that to be expected under natural conditions.

10-years' objective:-Adoption by a majority of nations of an effective International Convention on the Conservation of Biological Diversity.

2. Tropical Forests

40-years' goal:-To ensure that $50 \%$ of existing tropical forests are conserved through a careful balance of protection and sustainable exploitation.

10-years' objective:-Establishment of a comprehensive network of effectively managed sites appropriately distributed in all 57 rain-forest countries, so as to include populations of at least $80 \%$ of all rain-forest vertebrates.

3. Coastal Areas

40-years' goal:-To ensure legal and effective protection of coastal areas and landscapes on at least onethird of the coastline of each maritime country.

10-years' objective: Establishment of a global system of coastal-marine reserves in which all coastal States participate.

4. Islands

40-years' goal:-To implement practical measures in all biogeographic regions for the conservation of the unique biological diversity of islands, especially those with significant and essentially natural floras and faunas.

10-years' objective:-Identification and effective protection of at least 50 major centres of island biological diversity.

\section{B. Conservation and Development}

\section{Restoration Ecology}

40-years' goal:-To apply the scientific knowledge now available to the restoration of at least $30 \%$ of the degraded lands in all regions.

* Received from IUCN Secretariat as a document 'which we drew up in conjunction with the IUCN 40th anniversary celebrations; - Ed. practical methods that can lead to the restoration to sustainable, productive use of degraded habitats representative of all major types of ecosystems-especially those affected by aridity, desertification, deforestation, or erosion.

\section{Population}

40-years'goal:-To reduce the current growth-rate of human populations to levels which the environment can support under conditions that provide for a sufficient dignity and quality of life.

10-years' objective:-Ensuring that national conservation and resource management strategies take full account of the limited capacity of the land to support people under conditions of human dignity, and promotion within such strategies of educational, social, economic, and health care, policies which achieve such a balance.

\section{Education and Information}

40-years' goal:-To have all key sectors of the world community understand and accept the concepts and practices of conservation and sustainable development.

10-years' objective:-Development of education and public information programmes in all countries, so that the general public and those who take decisions on their behalf are aware of the status and trends of their national living resources and the imperatives for their sustainable, long-term management.

\section{Economics}

40-years'goal:-To develop and adopt new economic methodologies that will secure the proper evaluation of environmental resources, and reduce the risk of their destructive exploitation for short-term gain.

10-years' objective:-Ensuring that national accounting systems incorporate measures of biological wealth, and that they treat the depletion of resources such as forests and biological diversity as a loss rather than income. 